\title{
Carpathian Biosphere Reserve (Ukraine): Towards Participatory Management
}

\author{
Juliane Geyer, Fedir D. Hamor \& Pierre L. Ibisch
}

Keywords: biosphere reserve, protected area management, stakeholders, participatory approach, Carpathians, Ukraine

\section{Abstract}

The Carpathian Biosphere Reserve (CBR) in Ukrainian Transcarpathia, formally recognized by UNESCO in 1992, is one of the most important protected areas in Europe. In 2007, the beech forests of Uholka were included into the UNESCO World Heritage Site Primeval Beech Forests of the Carpathians because of their uniqueness. In the course of the reserve's spatial development and the potential integration of populated areas, participatory management arises as a crucial challenge. A first study of local stakeholders (private and state forestry enterprises, local communities), their attitudes and potential conflicts as well as synergies was conducted in 2008. Local communities, especially authorities, generally have a fairly positive attitude towards sustainable development and cooperation. Conflicts exist mainly between the CBR and the forestry sector, which is presently least oriented towards sustainability and rather focussed on economic revenue. We identified a common, but not insurmountable, lack of communication and cooperation between stakeholders. Local acceptance of the CBR is growing. Therefore the CBR can take the lead in applying a more integrative and participatory conservation management approach.

\section{Introduction}

The Carpathians are one of the biologically richest regions in Central Europe. In addition to many rare and endemic species, they harbour large areas of near-natural ecosystems and the greatest remaining reserve of old-growth forests outside Russia (WWF 2008). The old-growth, so-called 'primeval', beech forest in the Ukrainian massif Uholka-Shyrokiy Luh is the largest contiguous area of its kind in Europe (Commarmot et al. 2007). It has been part of the UNESCO World Heritage Site Primeval Beech Forests of the Carpathians since 2007 (UNESCO 2008b). Those old-growth forests and other areas of exceptional conservation value are included in the Carpathian Biosphere Reserve (CBR) and make it one of the most important protected areas in Europe. Its outstanding significance is further reflected in its recognition as a UNESCO Biosphere Reserve in 1992 and the award of the European Diploma for Protected Areas in both 1997 and 2007. It was established as a rapovidnyk (strict nature reserve) in 1968 and gradually enlarged to its current size of 53600 ha. Over $80 \%$ of the area is covered with forest, large parts are very well preserved and characterized by structures and ecological processes hardly influenced by human impacts. The CBR accommodates a considerable diversity of species, many of which are listed in the Red Data Books of Ukraine and Europe. This includes a significant number of endemics (Brändli \& Dovhanych 2003; Hamor 2005). The CBR's territory consists of five semi-detached

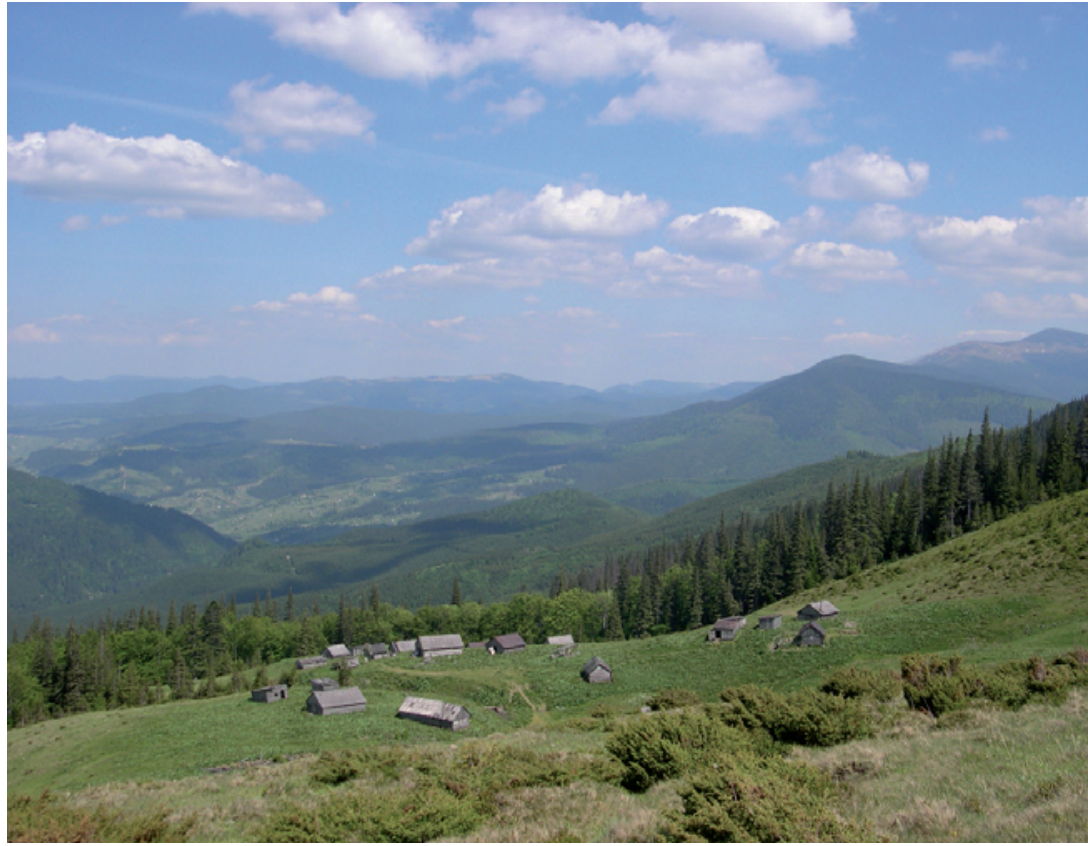

Traditional mountain cattle farm near Dragobrat.

Carpathian Biosphere Reserve (CBR) C Juliane Geyer

massifs and three isolated nature reserves, creating a cluster structure (Hamor 2005). The CBR's functional territorial zoning comprises the core zone (strict protection) and three zones where extensive land uses like selective logging, grazing, picking of berries and mushrooms and hay-making are allowed in a restricted regime. The CBR directly owns 31995 ha of the territory (Hamor 2005). 


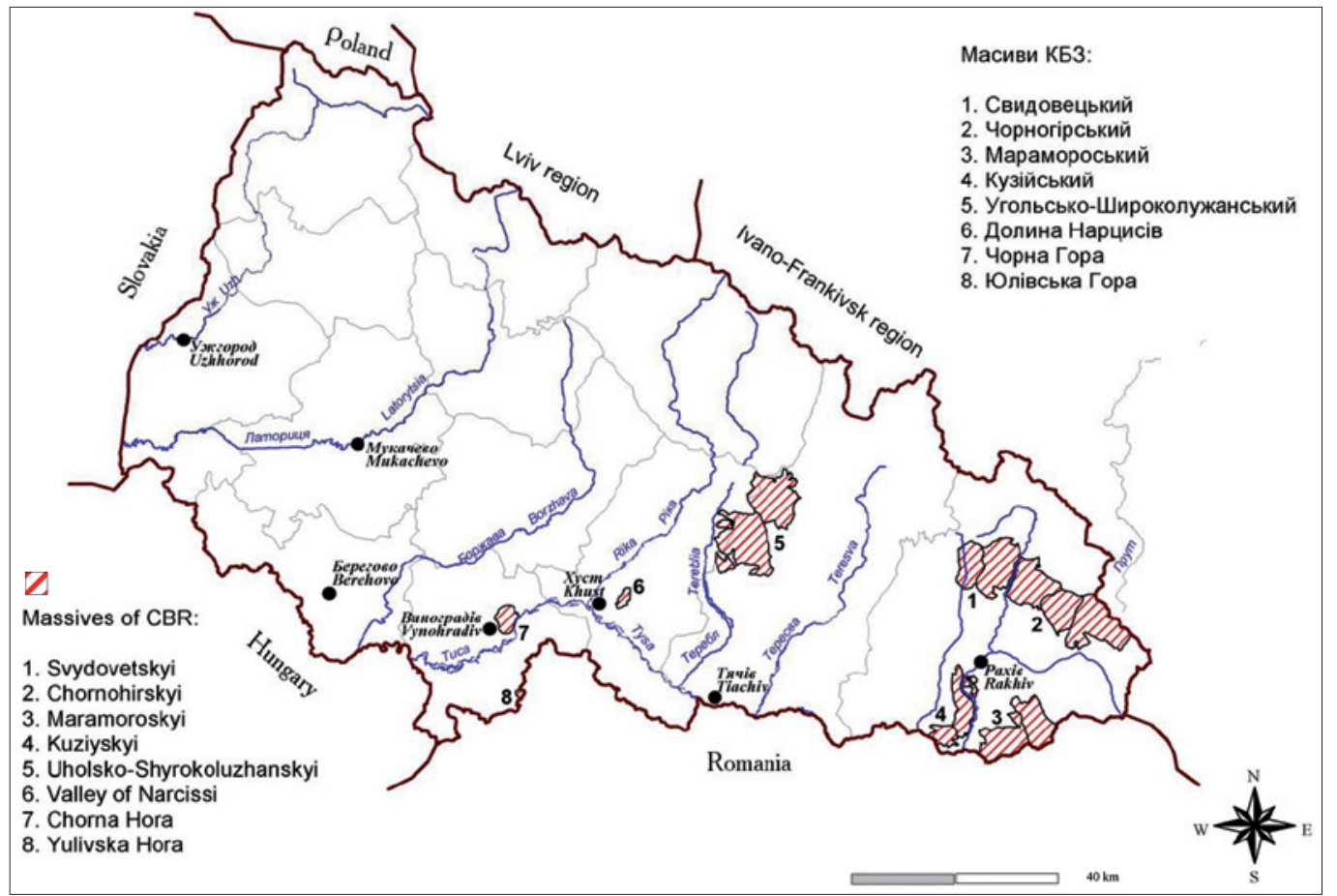

Figure 1 - Map of the CBR and its massifs, by permisssion of Yuriy Berkela (CBR), pers. comm. 2008

The region is facing rapid socio-economic development and has been undergoing many changes and transformations since 1991. Factors impacting on the region include the decollectivization of agriculture and forestry, high unemployment rates and work migration, land privatization, inflation and global developments such as climate change. Kuemmerle et al. (2009) found that unsustainable forest use and illegal logging persist, resulting in continued loss of older forests and their services as well as in the ongoing fragmentation of some of Europe's last large mountain forests as found in and around the CBR. It has been suggested that the integration of local interest groups into decision-making has been rather deficient and the high dependence of various actors on natural resources for their business and livelihood is causing conflicting interests and low acceptance of the CBR (Wallner 2005; Kruhlov 2008, pers. comm.). In fact, contrary to the classic Biosphere Reserve concept, settlements have so far not been included in the reserve. The reasons for this can be found in history.

The public used to be excluded from decision-making in the management of protected areas in post-socialist European countries (Lawrence 2008; Rodela \& Udouc 2008; Svajda 2008). In conditions like those found in many post-socialist countries, which are facing rapid social, economic and political change, participatory, ecosystem-based approaches have turned out to be especially valuable (Lawrence 2008). In the Ukraine, the aspect of participatory management has only recently started to emerge. Decisions and management practices are more likely to be implemented and accepted if key actors support them, and early involvement of stakeholders prevents surprises and leads to a more sustained commitment (Stoll-Kleemann \&
Welp 2006). From a case study symposium, Lawrence (2008) concludes a need for new approaches in those countries due to their specific characteristics. Experience needs to be created to develop an understanding of how participatory management and conservation might work in those countries.

In her study about perceptions of biosphere reserves by local people, using the CBR as one example case, Wallner (2003) concluded that knowledge of the ideas and thoughts of the local population in the surroundings of a BR is among the most crucial factor in the successful and thus sustainable management of protected areas.

The aim of this study is therefore to add to the pool of experiences about participative management in post-socialist countries and to provide first insights as well as an essential step towards active implementation of the concept in the CBR by analysing local stakeholders and their relationships.

\section{Methods}

Study area

The study was conducted in Rakhiv District (Rakhivski Rayon, N $47^{\circ} 50-48^{\circ} 24^{\prime}$, E $24^{\circ} 00^{\prime}-24^{\circ} 36^{\prime}$, see Figure 1) in the Eastern part of Transcarpathia (Zakarpatska Oblast). Four of the five big massifs of the CBR are located in Rakhiv District, representing 64\% (34222 ha) of the reserve's territory.

According to local sources, Rakhiv District has a population of 90000 , spread across 21 mostly montane settlements; 52000 people live in villages, 38000 are considered urban population. The alpine areas are almost devoid of permanent settlements, but over the summer there are still many traditional Hucul cattle 
Table 1 - Stakeholders in the area of the CBR

\begin{tabular}{|c|c|c|c|}
\hline Local land users & Other local actors & Non-local government actors & $\begin{array}{c}\text { Non-local/international actors } \\
\text { acting locally }\end{array}$ \\
\hline $\begin{array}{l}\text { - Local population } \\
\text { - Village councils } \\
\text { - State Forestry Enterprises } \\
\text { - Private wood-processing } \\
\text { businesses }\end{array}$ & $\begin{array}{l}\text { - Private non-forestry busi- } \\
\text { nesses (e.g. tourism) } \\
\text { - Saulyak LLC gold mine } \\
\text { - Local NGOs (Tysa, Ecological } \\
\text { Club "Carpathians") } \\
\text { - Private hunting and fishing } \\
\text { associations } \\
\text { - Protected areas bordering } \\
\text { the CBR (Carpathian Na- } \\
\text { tional Nature Park in Ivano- } \\
\text { Frankivsk District, Maramures } \\
\text { Mountains Nature Park in } \\
\text { Romania (Parcul Natural } \\
\text { Muntii Maramuresului)) }\end{array}$ & $\begin{array}{l}\text { - Ministry of Environmental } \\
\text { Protection of Ukraine } \\
\text { - State Committee of Forestry } \\
\text { - District Council and District } \\
\text { Administration } \\
\text { - State Administration of Envi- } \\
\text { ronmental Protection in the } \\
\text { Transcarpathia Region }\end{array}$ & $\begin{array}{l}\text { - FORZA (Swiss-Ukrainian } \\
\text { Forest Development Project in } \\
\text { Zakarpattya) } \\
\text { - WWF } \\
\text { - Heifer International } \\
\text { - Scientific institutions, uni- } \\
\text { versities (e.g. Lviv and Kyiv } \\
\text { Universities) } \\
\text { - International scientists and } \\
\text { funds (e.g. Royal Dutch Soci- } \\
\text { ety for Nature Conservation, } \\
\text { Swiss Federal Institute for } \\
\text { Forest, Snow and Landscape } \\
\text { Research WSL) } \\
\text { - Tourists }\end{array}$ \\
\hline
\end{tabular}

herders on the alpine meadows (polonynas) tending their flocks. Most of the area is forested, mainly by spruce and beech-fir forests, and forestry plays an important economic role in the region. Because of the topography, agriculture is not very well developed.

\section{Study procedure}

The methodological procedure of this qualitative study was guided by the steps commonly used in stakeholder analysis (see e.g. Grimble 1998; Varvasovszky \& Brugha 2000; Mayers 2005; WWF 2005; IUCN 2008): Identification of principal stakeholders, investigation of stakeholder interests, characteristics, circumstances and frame, assessing stakeholder power and potential, identifying patterns and contexts of interaction and conflicts, and defining options for management.

First, numerous stakeholders of the area of the CBR were identified (Table 1). For more profound subsequent investigations, local land users were defined as key stakeholders because of their claims over and direct dependence on local resources (WWF 2005): the CBR administration, state forestry enterprises, local residents, village councils and private wood-processing businesses.

The subsequent analysis is based on information gathered in 50 semi-structured face-to-face interviews with representatives of key stakeholders (see Table $2 \& 3$ for guiding themes). Interviewees were chosen by theoretical sampling, i.e. on the basis of their relevance and usefulness for understanding a particular question or issue (Lamnek 1993; Swaffield 1998) and the snowball technique. In the case of the local population, the sampling was slightly more random and interviews were conducted with 17 females and 8 males (11 aged 40-60, the others equally older and younger) in nine villages. After audio-recorded interviews were transcribed, the most important themes and topics (categories) were extracted and their respective attributes collected (coding) (cf. grounded theory Glaser \& Strauss, 1967).

We investigated stakeholder characteristics and positions, then assessed stakeholder importance and influence qualitatively using the following definitions: importance (potential) is the extent to which needs and interests of a stakeholder are a priority for the system or issue at hand (IUCN 2008). Influence (power) is the ability to persuade or coerce others into making decisions and following certain courses of action (Salam $\&$ Noguchi 2006). Interactions and relationships were then more closely studied by identifying common and conflicting / competing interests. This was followed by an identification and assessment of common grounds and (potential) conflicts. Finally, we deduced the implications for future causes of action and management approaches.

Table 2 - Summary of interview partners

\begin{tabular}{|c|c|c|c|c|c|}
\hline & Village dwellers & Village councils & $\begin{array}{c}\text { State Forestry } \\
\text { Enterprises }\end{array}$ & $\begin{array}{l}\text { Private wood } \\
\text { companies }\end{array}$ & CBR staff \\
\hline $\begin{array}{l}\text { Number of } \\
\text { interviews }\end{array}$ & 25 & 6 & 11 & 2 & 6 \\
\hline Specification & $\begin{array}{l}\text { Yasinya-Keveliv, } \\
\text { Kvasy-Trostianiec, } \\
\text { Hoverla, Kostylivka, } \\
\text { Dilove, Luh, Ko- } \\
\text { sivska Polyana, Bilyn, } \\
\text { Lazeshchyna }\end{array}$ & $\begin{array}{l}\text { Lazeshchyna, Kvasy, } \\
\text { Luhy, Kostylivka, } \\
\text { Dilove, Kosivska, } \\
\text { Polyana }\end{array}$ & $\begin{array}{l}3 \text { main offices (Rakhiv, } \\
\text { Yasinya, Bychkiv) } \\
\text { - } 6 \text { local offices (Lazesh- } \\
\text { chynske, Svydovecke, } \\
\text { Hoverlyasnke, Bilot- } \\
\text { ysyanske, Rakhivske, } \\
\text { Kostylivske Lisnyctvo) }\end{array}$ & & $\begin{array}{l}\text { - } 3 \text { scientists } \\
\text { - } 3 \text { rangers }\end{array}$ \\
\hline
\end{tabular}


Table 3 - Themes and categories used to guide semi-structured interviews with the SFEs (State Forestry Enterprises), the local population, village councils and the CBR

\begin{tabular}{|c|c|}
\hline $\begin{array}{l}\text { SFEs } \\
\text { - General information about SFE/local forestry district } \\
\text { - Forest management } \\
\text { - Role of forestry in the region } \\
\text { - Interaction/ conflicts with other land users (esp. local population) } \\
\text { - Interaction with private wood businesses } \\
\text { - CBR (relationship, interaction) } \\
\text { - CBR extension } \\
\text { - Sustainability } \\
\text { - External projects and partners (e.g. FORZA) }\end{array}$ & $\begin{array}{l}\text { Local population } \\
\text { - General information about household and provisions } \\
\text { - Life in the village (employment, administration, participation, } \\
\text { people's interaction) } \\
\text { - Role of landscape } \\
\text { - Land use, restrictions and conflicts } \\
\text { - Firewood } \\
\text { - Interaction with forest enterprises } \\
\text { - CBR - interaction and attitudes } \\
\text { - Tourism } \\
\text { - Wishes/visions for future }\end{array}$ \\
\hline $\begin{array}{l}\text { Village councils } \\
\text { - General information about the village and population } \\
\text { - Village administration and participation } \\
\text { - Land use and restrictions } \\
\text { - Forestry and SFEs - dependencies and relationships } \\
\text { - CBR - interaction and relationship } \\
\text { - Concept of biosphere reserves } \\
\text { - Other organizations and partners } \\
\text { - Privatization } \\
\text { - Tourism } \\
\text { - Wishes/visions for future }\end{array}$ & $\begin{array}{l}\text { CBR } \\
\text { - Management of CBR } \\
\text { - Forestry and SFEs } \\
\text { - Land use by local population } \\
\text { - Relationships with neighbours } \\
\text { - Extension } \\
\text { - Integration of communities and other stakeholders } \\
\text { - Interaction with other projects and partners } \\
\text { - Internal and external conflicts } \\
\text { - Tourism }\end{array}$ \\
\hline
\end{tabular}

\section{Results and discussion}

Inventory of stakeholders and their attitudes, positions and action

The Carpathian Biosphere Reserve (CBR): the CBR is a state agency and reports directly to the Ukrainian Ministry for Environmental Protection. Its management is supporting traditional land uses in the development zone of the CBR area. Currently, the $\mathrm{CBR}$ is trying to improve conservation effectiveness by connecting its isolated massifs. Expansion planning integrates local communities and state forestry enterprises into decision-making. Furthermore, the CBR administration is planning to establish a stakeholder council for conservation and sustainable land use in the region, which is the first major step towards more participation and better integration of local stakeholders. From its strong position as a state agency and its significant international reputation, the CBR is very powerful with respect to local conservation and sustainable land use.

Local population: local people are the main agricultural land users and the majority of the 90000 inhabitants are engaged in small-scale agricultural activities for their own use. Almost all of them live outside the CBR, but a major part of their land use takes place inside the CBR, especially cattle and sheep grazing on polonynas. Utilization rights of and guaranteed access to grazing areas are crucial to most inhabitants. Unemployment rates are high. Most locally employed people work in the forestry sector. Additional local income is generated from small-scale tourism activities, fishing, the sale of non-timber forest products and illegal logging. The local population carries a high potential for the development of the CBR and the region, since a substantial part of their livelihood still depends on the land. The influence of local people is fairly low since they are rather marginalized in decision-making, partly by the lack of direct decision-making powers.

Village councils: there are 22 communities in Rakhiv District, administered by village councils consisting of the village head(s) and an assembly of delegates. They are key actors in decision-making at local level. The importance of village councils lies in their position of owning and administrating village land as well as their representation of the local people. The latter also implies relatively high importance. As they are fairly autonomous institutions, their power can be categorized as high. They have some influence on decisions concerning conservation in the area, e.g. through their vote in the matter of CBR extension. They also organize and administer a major part of the agricultural land use.

State Forestry Enterprises: the three state forestry enterprises (Yasinya, Rakhiv, Vel. Bychkiv) are the most important land managers in Rakhiv District as most of the land is forest. They enjoy economic autonomy and receive almost no subsidies from the state. Almost all forest resource users depend on them. Their importance as well as their potential can be categorized as high. Their basis of existence are the forestry operations and the income generated by them. Thus their interests could constitute a major impediment for sustainable use of resources and conservation in the area. Being state institutions and only bound to higher forestry authorities, they enjoy considerable power in the region.

Private wood-processing enterprises: private wood-processing businesses make up the main branch of private businesses in the region (approx. 20-25 in and around the towns of Yasinya, Rakhiv and Vel. Bychkiv). They are dependent on forest resources by 
Table 4 - Fields of (a) complementary and similar interests and (b) conflicting or competing interests between main land users. The depth of background shading indicates the scope for common ground or conflicting interests respectively.

$C B R=$ Carpathian Biosphere Reserve, $P W C=$ Private wood-processing companies, SFE $=$ State Forestry Enterprise

\begin{tabular}{|c|c|c|c|c|}
\hline (a) & Local population & Village councils & SFEs & PWCs \\
\hline CBR & $\begin{array}{l}\text { - Traditional land use } \\
\text { - Development of tourism } \\
\text { - Protection of landscape }\end{array}$ & $\begin{array}{l}\text { - Secure traditional land-use } \\
\text { rights } \\
\text { - Sustainable economic } \\
\text { development } \\
\text { - Development of tourism }\end{array}$ & $\begin{array}{l}\text { - Protection of old forests } \\
\text { and valuable natural } \\
\text { assets }\end{array}$ & - Local supply of wood \\
\hline PWCs & - Income through forestry & - Income through forestry & - Exploitative forestry & \\
\hline Village councils & $\begin{array}{l}\text { - Development } \\
\text { - Secure land-use rights } \\
\text { - People's welfare }\end{array}$ & & & \\
\hline (b) & Local population & Village councils & SFEs & PWCs \\
\hline SFEs & $\begin{array}{l}\text { - Utilization of forest } \\
\text { resources }\end{array}$ & $\begin{array}{l}\text { - Forestry roads and logging } \\
\text { practices }\end{array}$ & & \\
\hline Village councils & - Cooperation with CBR & & & \\
\hline
\end{tabular}

either buying wood from the state forest enterprises or by direct logging concessions on state territory. Their political power is relatively low, but due to their important socio-economic role in local communities they have a relatively high influence, mainly in monetary terms.

Others: other stakeholders include governmental actors, such as administrations and different ministries, as well as other local actors like NGOs. We also identified non-local and international actors as very important for the development of the CBR, since most of them already are concerned with issues of sustainable development in the area (e.g. FORZA, WWF) and could be valuable partners (see Table 2).

Common and conflicting/competing interests Both common and conflicting interests exist amongst land users (see Table 4). The strong interest in the continuation of exploitative forestry operations in the area is the basis for the large common ground between state and private forestry enterprises. This powerful bond ensures close cooperation and high influence by the forestry sector in the region. Village councils and the local population also correspond strongly in their interests. Both aim at people's welfare through regional development, secured land-use rights and prosperity of communities. The main areas of conflicting or competing interests between individual stakeholder groups are found in forestry practices and the utilization of wood as well as in anticipated land-use restrictions to be imposed by the CBR.

\section{Overall conflict potential}

Table 5 shows where disagreement or conflict situations presently exist or might arise in future. Highest potential for disagreement persists between private forestry enterprises and the CBR. Their interests and aims are very different, even opposed. However, there

Table 5 - Overall conflict potential as assessed from evaluating conflicting and common interests.

$C B R=$ Carpathian Biosphere Reserve, $P W C=$ Private wood-processing companies, SFE $=$ State Forestry Enterprise

\begin{tabular}{|c|c|c|c|c|}
\hline & Local population & Village councils & SFEs & PWCs \\
\hline CBR & & & & \\
\hline PWCs & & & & \\
\hline SFEs & & & & \\
\hline Village councils & & & & \\
\hline
\end{tabular}


is very little direct contact between those two interest groups and conflicts are mainly decided via other actors and hidden in decision-making processes.

There is also relatively high potential for conflict between the CBR and local people as well as the state forestry enterprises (SFE), but relationships seem to develop into different directions. With increased understanding and acceptance of the CBR, the conflict potential regarding the local population is decreasing. Further intentions of expanding the CBR and incorporating SFE property increase the probability of conflicts between those main land managers. The state forestry enterprises' resentment of the CBR is mainly built upon their economic autonomy and total dependence on generating revenues from forestry, in contrast to the CBR, which receives financial support from the government.

Only moderate potential of conflict can be expected between the village councils and the three non-communal land users, since dialogue exists and negotiations are under way. Due to their relatively high power, they have the possibility to sort out conflicts before they arise.

The relationship between local people and forestry enterprises carries only medium conflict potential as common interests still outweigh most conflicting ones. There is a slightly lower potential for conflict between local people and private wood-processing companies because of their direct relationship of employment or business ownership.

Least conflict can be expected both within the commercial forestry sector and between local people and their village councils. In most thematic fields, forestry actors on the one hand and communities on the other form strong entities and the respective partners show a strong basis of cooperation.

\section{Implications for management and planning}

As they become increasingly aware of the significance of sustainability and conservation, local communities, especially village heads, are very important for the CBR management. Valuing their home landscapes, still pursuing traditional land uses and being dependent on local natural resources, they hold a position that is certainly in support of sustainable development. In order to achieve it, the village councils and the CBR need to develop a strong dialogue. Their growing interest in conservation and sustainable development will make cooperation possible and their great local influence makes success more likely.

Interests of the local population should have priority in planning and management since they have inherited land-use rights to the area and their livelihood still depends largely on the land. Only in meeting their needs and actively involving them will sustainable development be possible and conservation successful. One such need is that for an adequate and affordable supply of fuel or energy for heating and cooking. This could be achieved by sourcing firewood from com- munity forestry or by finding other energy sources, such as small hydropower stations, which are already being tested in the area. Another issue is the need for secured land-use rights and access to mountain meadows (polonynas). Continuation of traditional land uses, especially sheep farming, plays a very important role in the sustainable development of the region. As suggested by local authorities, sheep farming might have to be reorganized and adjusted to modern conditions. Generally, there is a clear need for securing and generating local employment opportunities to stop further migration as well as illegal actions. Local employment will secure people's incomes and help keep a local identity and attachment to the land, which is necessary to reduce resource exploitation and degradation. Development of ecotourism might be one possibility, but it needs gentle guidance to avoid overuse and negative rebounds, especially for ecological systems. Local people need to be empowered by more participatory strategies. Contact and information need to be much extended and community outreach from state agencies enhanced and stabilized.

The forestry-related actors are presently least oriented towards sustainability and rather focused on economic success. A fundamental change in forest management is necessary. However, it cannot be achieved at local or even regional level. Changes have to happen at national level and are slowly setting in. Locally, forest enterprises should seek contact with other actors and at least engage in dialogue and cooperation as already initiated by the efforts of international organizations. Instead of indulging in personal power struggles, the CBR and village councils should strengthen their common ground to ensure sustainable development and with it benefits for everybody. Generally, a community forestry approach might be considered for the future, which will answer the need for generating local incomes as well as supplying resources for private individuals and businesses.

The CBR administration has the responsibility of being a key actor for integrative conservation management, including sustainable development in the region, by coordinating and managing joint efforts. By introducing modern, integrative, participatory and pro-active conservation management strategies, the CBR can maintain and enhance its status as a site of great international importance for protection and at the same time function as an engine for the region, ideally even as a model region for the whole Carpathian Ecoregion. Specific recommendations include the absolutely crucial activation of the dormant stakeholder council, the establishment of which is already a very progressive and exemplary step towards increased communication and cooperation between stakeholders.

Community outreach needs to be extended to the local people and contact sought directly. Invitations to community meetings should be better acknowledged as opportunities for building trust and cooperation and be followed up in future. The CBR will have to 
take on concerns expressed by local authorities and residents. The cooperation with other initiatives which work regionally for sustainable development will have to be recognized as a great opportunity for both the reserve and the region and be extended further. Even though it might take some time to overcome existing barriers, the high potential, creativity and progressive thinking of CBR staff could ease the way, if acknowledged and given the chance to develop.

\section{Conclusion}

This study adds to the understanding of participatory conservation in post-communist contexts, which is only beginning to emerge, and constitutes a basis for participatory conservation management and sustainable development in the area of the CBR. It shows that there are several common but also some conflicting interests between local stakeholders. The acceptance of the CBR and the acknowledgement of its key role as land manager and promoter of sustainable land use in the region are growing. However, communication and cooperation among stakeholders are rather deficient. The present overview of stakeholders and their relationships is a novel approach for the CBR. Lawrence (2008) considers relatively basic and not particularly innovative levels of participation, such as understanding stakeholder perspectives, fundamentally necessary and very important in the post-socialist context. According to him, this is already a great achievement in the process of introducing participatory conservation to the CBR. It paves the way for improved communication between stakeholders. The idea of the stakeholder council should be further pursued to enable discussion among stakeholders about their vision of a common future of the region as a biosphere reserve and world heritage site. Local communities are already showing an interest in such cooperation. Special efforts will have to be made vis-à-vis the forestry sector.

In order to ensure the success of long-term conservation objectives, an integrated and participatory management approach is needed and in line with various international conservation concepts, such as the Ecosystem Approach of the Convention of Biological Diversity (CBD) and the Seville Strategy and Madrid Action Plan of the UNESCO Man and the Biosphere (MAB) Programme (UNESCO 1996; 2008a). Biosphere reserves are model areas for sustainable development, integrating biodiversity conservation and sustainable land use (UNESCO 2007), i.e. a land use that does not compromise either the long-term production potential and the provision of ecosystem goods and services, or the ecosystem functionality required to ensure resilience and adaptive capacity.

Apart from those international frameworks, regional initiatives too require more integrative conservation and sustainable development, especially in the Carpathian Ecoregion, such as the Carpathian Ecoregion Initiative (CERI), a platform of NGOs and institutes working within the framework of the Carpathian Convention (CERI 2008). The Carpathian Convention provides the framework for cross-border cooperation and multisectoral policy coordination, a platform for joint strategies for sustainable development and a forum for dialogue between all stakeholders involved in the Carpathian Ecoregion (The Carpathian Convention 2008). Those concepts integrate the idea of participatory management, acknowledging that sustainability and the achievement of long-term conservation objectives are only possible if you integrate communities and other stakeholders into decision-making and share the benefits. Management is based on the cooperation of many partners, mostly government agencies and other sections of society, such as local people and communities, NGOs and the private sector (Kothari 2006). In improving stakeholder dialogue and integration into conservation planning, the CBR is well on the way towards becoming a model region for conservation and sustainable development in the Ukrainian Carpathians and even for the whole Carpathian Ecoregion.

\section{Acknowledgements}

We thank our local translators, interview partners and assisting CBR staff for their cooperation. Special thanks are due to the Studienstiftung des deutschen Volkes, the University of Applied Sciences Eberswalde and the Academy of Sciences and Literature Mainz ("Biodiversity in Change" Programme, Prof. Dr. Wilhelm Barthlott) for supporting this study. We also thank Ivan Kruhlov (University of Lviv) for the information provided in personal communication.

\section{References}

Brändli, U.-B. \& Y. Dovhanych 2003. Urwälder im Zentrum Europas. Ein Naturführer durch das KarpatenBiosphärenreservat in der Ukraine. Bern.

CERI. Carpathian Ecoregion Initiative. Available at: http://www.carpates.org/ (accessed: 15/08/08)

Commarmot, B., V. Chumak, P. Duelli, N. Küffer, P. Lovas \& Y. Shparyk 2007. Buchenurwälder als Referenz für Naturschutz: Forschungsergebnisse aus den ukrainischen Karpaten. Natur und Landschaft 9, 10: 398-400.

Glaser, B.G. \& A.L. Strauss 1967. The discovery of grounded theory: strategies for qualitative research. New York.

Grimble, R. 1998. Stakeholder methodologies in natural resource management. Socio-economic methodologies. Best Practice Guidelines. Chatham, UK: Natural Resources Institute.

Hamor, F.D. 2005. Carpathian Biosphere Reserve: conservation and sustainable utilisation. In: Commarmot, B. \& F.D. Hamor (eds.), Natural Forests in the Temperate Zone of Europe - Values and Utilisation. Conference 13-17 October 2003, Mukachevo, Ukraine. Proceedings: 30-35. Birmensdorf, Swiss Federal Research Institute WSL; Rakhiv: Carpathian Biosphere Reserve. 
IUCN. Situation analysis - an approach and method for analyzing the context of projects and programme. Available at: http://cmsdata.iucn.org/downloads/approach_and_method.pdf (accessed: 22/05/08)

Kothari, A. 2006. Collaboratively managed protected areas. In: Lockwood, M., G. Worboys \& A. Kothari (eds.), Protected areas management: a global guide: 528-548. London.

Kuemmerle, T., O. Chaskovskyy, J. Knorn, V.C. Radeloff, I. Kruhlov, W.S. Keeton \& P. Hostert 2009. Forest cover change and illegal logging in the Ukrainian Carpathians in the transition period from 1988 to 2007. Remote Sensing of Environment 113, 6: 1194-1207.

Lamnek, S. 1993. Qualitative Sozialforschung. Band 2: Methoden und Techniken. Weinheim.

Lawrence, A. 2008. Experiences with participatory conservation in post-socialist Europe. International Journal of Biodiversity Science and Management 4, 4: 179-186.

Mayers, J. 2005. Stakeholder power analysis. Power tools series. International Institute for Environment and Development, London.

Rodela, R. \& A. Udouc 2008. Participation in nature protection: does it benefit the local community? A Triglav National Park case study. International Journal of Biodiversity Science and Management 4, 4: 209-218.

Salam, M.A. \& T. Noguchi 2006. Evaluating capacity development for participatory forest management in Bangladesh's Sal forests based on '4Rs' stakeholder analysis. Forest Policy and Economics 8, 8: 785-796.

Stoll-Kleemann, S. \& M. Welp 2006. Towards a more effective and democratic natural resources management. In: Stoll-Kleemann, S. \& M. Welp (eds.), Stakeholder dialogues in natural resources management. Theory and Practice: $17-39$. Berlin.

Svajda, J. 2008. Participatory conservation in a postcommunist context: The Tatra National Park and Biosphere Reserve, Slovakia. International Journal of Biodiversity Science and Management 4, 4: 200-208.

Swaffield, S. 1998. Frames of reference: a metaphor for analyzing and interpreting attitudes of environmental policy makers and policy influencers. Environmental Management 22, 4: 495-504.

The Carpathian Convention. The Convention on the protection and sustainable development of the Carpathians. Available at: http://www.carpathianconvention.org/index.htm (accessed: 22/10/08)

UNESCO 1996. Biosphere Reserves: the Seville Strategy and the Statutory Framework of the World Network. Paris: UNESCO.

UNESCO 2007. Biosphere reserves: reconciling the conservation of biodiversity with economic development. Available at: http://www.unesco.org/mab/BRs. shtml (accessed: 03/06/08)

UNESCO 2008a. Madrid Action Plan for Biosphere Reserves (2008-2013). Paris: UNESCO.

UNESCO 2008b. Primeval beech forests of the Carpathians. UNESCO World Heritage List. Available at: http://whc.unesco.org/en/list/1133/ (accessed: $21 / 10 / 08)$
Varvasovszky, Z. \& R. Brugha 2000. How to do (or not to do) ... A stakeholder analysis. Health policy and planning 15, 3: 338-345.

Wallner, A. 2003. Local people's perceptions of protected areas: a cross-cultural study In: SAMPAA (eds.), 5th International Conference on Science and Management of Protected Areas. Making ecosystem based management work. University of Victoria, Victoria, British Columbia, Science and the Management of Protected Areas Association.

Wallner, A. 2005. Biosphärenreservate aus der Sicht der Lokalbevölkerung. Schwei und Ukraine im Vergleich. Dissertation. Birmensdorf.

WWF 2005. Cross-cutting tool. Stakeholder analysis. Resources for Implementing the WWF Standards.

WWF. WWF's work in the Danube-Carpathian region. Available at: http://www.panda.org/about_ wwf/where_we_work/europe/what_we_do/danube_carpathian/index.cfm (accessed: 22/10/08)

\section{Authors}

\section{Juliane Geyer ${ }^{1}$}

Master thesis on stakeholders and land use of the Carpathian Biosphere Reserve, UA. Currently doctoral candidate on adapting nature conservation strategies to global change.

jgeyer@fh-eberswalde.de

Pierre Leonhard Ibisch ${ }^{1}$

Born 1967. Professor for Nature Conservation at University of Appl. Sciences Eberswalde. Currently holding a Research Professorship on Biodiversity and Natural Resource Management under Global Change. Strong background in biodiversity research, development (cooperation), conservation and global change. pibisch@fh-eberswalde.de.

\section{Prof. Dr. Fedir D. Hamor²}

Born 1951. Graduated at Uzhgorod National University. $\mathrm{PhD}$ and Doctor degrees in biology (botany). Since 1987 director of the Carpathian Biosphere Reserve. Academician of the National Ecological Academy of Ukraine.

${ }^{1}$ University of Applied Sciences Eberswalde, Faculty of Forest and Environment, Alfred-Möller-Str. 1, 16225 Eberswalde, Germany

2 Carpathian Biosphere Reserve, 77 Krasne Pleso Street, Rakhiv 90600, Ukraine 